\title{
Article \\ On the Acceptance and Sustainability of Renewable Energy Projects-A Systems Thinking Perspective
}

\author{
Ana María González, Harrison Sandoval, Pilar Acosta and Felipe Henao * \\ Departamento de Gestión Organizacional, Facultad de Ciencias Administrativas y Económicas, \\ Universidad Icesi, Calle 18 No. 122-135, Cali 760031, Colombia; anagonzalezt@me.com (A.M.G.); \\ hsandoval@icesi.edu.co (H.S.); mdacosta@icesi.edu.co (P.A.) \\ * Correspondence: jfhenao@icesi.edu.co; Tel.: +57-2-5552334 (ext. 8208)
}

Academic Editor: Marc A. Rosen

Received: 26 September 2016; Accepted: 9 November 2016; Published: 12 November 2016

\begin{abstract}
Rapid population growth and increasing concern related to improving the living standards in impoverished communities without damaging the natural environment have drawn attention to the adoption of renewable energy systems (RES) around the world. Despite this global trend, the implementation of these projects has not succeeded completely in rural poor communities due to several factors, including social barriers faced at the time of their execution. These social barriers lead to poor acceptance of the projects and their consequent abandonment. Acceptance is a social construct that is influenced by several factors that need to be understood to achieve successful and sustainable results in the future. In this paper, we develop a conceptual model, based on principles of sustainability and systems thinking, to understand the interrelationships among the main factors that have been reported in the literature as key to determining the sustainability and community acceptance of RES projects. To do so, we review the existing literature on sustainability and social acceptance of RES and then construct a causal-loop diagram of their driving factors. While doing so, we also view the problem through the lens of the sustainable livelihoods framework, aiming to maintain the perspective of rural communities and observing the impacts of RES on their contextual reality. The resulting model helps to understand the multiple interactions that RES projects have with rural communities as well as identify potential intervention points for future projects. We end the paper with a discussion of the implications of the model and how can it be used to inform future rural energy decision making.
\end{abstract}

Keywords: renewable energy systems; sustainable livelihoods; community acceptance; causal-loop diagrams

\section{Introduction}

Renewable energy has become a top priority for governments and countries around the world. Some of the reasons for this shift, from traditional energy sources to renewable ways of producing energy, originate from the fact that regulatory bodies and multilateral and civil society organizations are demanding greener practices in energy production and consumption [1]. The continuous growing demand for energy worldwide has incentivized regions to become less dependent on fossil fuels in order to reduce their carbon footprint [2]. As a result, countries have taken an initiative towards the efficient use of resources and have added greener energy technologies to their portfolio of energy supply options [3]. Renewable energy systems (RES) are viewed as an alternative to conventional energy to address climate change and respond to an increasing energy demand worldwide. At the same time, on a smaller scale, RES have been advocated as a means to provide energy to the rural poor [2]. These types of projects are believed to improve the quality of life of communities, particularly in developing countries (e.g., [4-7]). 
Although renewable energy has the potential to be used worldwide to provide energy in a sustainable way to an ever-growing population, different cultural and societal factors can hinder the implementation of these technologies and compromise their future sustainability [8]. It has been observed that the acceptance and approval rate of these types of projects are not as expected due to several barriers posed by the inhabitants of the hosting communities. For example, wind power solutions have been criticised mainly because of concerns regarding noise, aesthetics and threats to flora, fauna and wildlife [9]. Large hydropower solutions have been criticised because flooding of a large territory affects the bio-diversity of the region, and projects of a much smaller scale have also been rejected by some communities because of their interference of rivers $[10,11]$. Geothermal power is believed to affect the stability of land, which may trigger earthquakes [12]. Solar photovoltaic systems have been ignored due to a lack of awareness about their affordability [13], and in some cases, the use of biomass is unattractive because of the emissions produced and the fact that the process must be carefully monitored and controlled [14].

Community acceptance is decisive for the success and sustainability of RES, as local opposition can lead to increasing costs and delays [15], or even the cancellation of projects [16]. Therefore, it is important to understand and anticipate the factors that underlie major social barriers, which may affect the acceptance and implementation of renewable energy technologies.

Research has considered the issue of acceptance [8], as public opposition to RES is common and is a complex problem involving several individual and collective rights [17]. Studies of social acceptance of RES began in the eighties, focusing on the lack of attention among key stakeholders regarding public attitudes towards wind power schemes [8]. Subsequent research examined the barriers to RES, depicting several factors ranging from economic to psychological variables (e.g., [15,18]). More recently, research has acknowledged the importance of having an integrated perspective of acceptance that includes both social and environmental aspects at the same time (e.g., $[9,19,20])$. Understanding community acceptance is not straightforward, since there are multiple causal relationships and interactions among various factors which make acceptance a complex systemic problem itself. However, understanding the phenomenon in a systemic manner may increase the chances of achieving successful and sustainable RES results in the future. Nevertheless, research has not yet comprehensively addressed the systemic nature of social acceptance of RES projects. Wüstenhagen et al. [8], for example, identified three factors that drive social acceptance, namely, socio-political, community and market factors, but ignored the causal relationships and interactions that exist among them. Understanding these factors, their interactions and feedback loops is the main purpose of this paper.

In this paper, we conduct a comprehensive literature review on the sustainability and community acceptance of RES and then develop a conceptual model, following the principles of causal-loop diagrams of systems thinking, by mapping the most commonly identified factors. The idea is to develop a conceptual causal model to help us understand the driving factors of RES acceptance and to visualise the dynamic structure of the system. Our mapping is also based on the sustainable livelihoods framework, which is an approach previously advocated as appropriate for determining the impacts of renewable energy interventions in rural communities, and, while reading the literature, to maintain the perspective of communities [2,21-23]. Our main contribution is therefore the development of the causal model for understanding the dynamics that drive community acceptance of RES projects and their sustainability in the long run. The diagram not only functions as a means to structure our own understanding of the literature but is also a starting point to suggest potential interventions for future RES projects.

The remainder of the paper is organised as follows. First, a discussion is presented regarding the terms social acceptance and community acceptance within the framework of renewable energy. The importance of community acceptance is emphasised as a determining factor for the sustainability of renewable energy projects. Then, we present the theoretical underpinnings of the sustainable livelihoods framework and the research methodology we followed. Subsequently, through a comprehensive literature review, a list of the major factors that appear to impact the sustainability and 
community acceptance of RES projects is identified. Thereafter, we develop a causal-loop diagram model to represent the dynamics of how these factors appear to interact with each other, and finally, some conclusions are presented.

\section{Community Acceptance and Renewable Energy}

Social acceptance of RES projects is a multidimensional concept in which community acceptance is one of the aspects to take into consideration. In this section, we explore the concept of acceptance, particularly community acceptance and its importance for the sustainability of RES projects.

Hizeroth et al. [24] define the term acceptance as all positive attitude parameters adopted by the parties involved in the planning of a project. An attitude parameter is a socio-cultural result influenced by people's perceptions and experiences, as well as their expectations of the improvement of their realities. To learn about attitude parameters, one should have a clear idea of the different groups within a community and how heterogeneous their expectations are (see also $[25,26]$ ).

Wüstenhagen et al. [8] distinguish three dimensions of social acceptance within the context of RES, namely: socio-political, market and community acceptances. Socio-political acceptance refers to the acceptance of society at its most general level, including the laws created to incentivise and institutionalize the use of renewables as energy solutions. Coherence between national initiatives and local contexts is also related to socio-political acceptance. Market acceptance concerns the adoption process of an innovation by consumers, investors and at the intra-firm level. With respect to the community, acceptance refers to local stakeholders, particularly residents and local authorities, hosting the projects. This is key for ensuring the sustainability of solutions, and it is usually lost when foreign or "non-local" investors and decision-makers disregard people's voices, opinions and participation. Opposition from local actors to projects has been depicted in the literature as the "NIMBY" (not in my back yard) phenomenon [26]. This last type of acceptance, i.e., community acceptance by rural poor communities, is the one we focus on in this paper.

Several factors positively or negatively influence community acceptance. Regarding site-specific factors, Jobert et al. [15] highlight the importance of economic incentives for inhabitants of territories and municipalities, as well as the ownership and previous use of the territory for long-term acceptance of RES projects. Other factors, such as the ability of the developer to create a network of local actors around the project, or the participation of the local population in the planning of the project, enhance acceptance $[15,19]$.

In terms of the decision making and management of RES projects, trust has been highlighted by several authors as one of the most important factors needed to gain the acceptance of communities $[15,17,18]$. Trust is enhanced if information is handled with transparency and accuracy throughout all stages of the project [19]. Trust is also gained if communities perceive that decisions are made to benefit all as opposed to only some parts of the community [17]. In other words, community acceptance is higher if the community perceives the decision process leading to implementation as fair (procedural fairness) and perceives fairness in the distribution of costs, risks and benefits of the project (distributional fairness) [18,19]. Therefore, when community residents are involved in the decision-making process and are continually engaged in policy development, final decisions (for instance, the siting of wind turbines) are less likely to be rejected later on once the project is established (see [25]).

Community acceptance is thus related to multiple interconnected factors. The case of large-scale dams is illustrative. In their paper, Tilt et al. [27] identified several social impacts related to the construction of large-scale dam projects, such as the resettlement of people living nearby, changes in the economy and employment structure, impacts on cultural aspects and impacts on health and gender relations. Such changes can also be the result of environmental changes in the biota of the river, affecting the communities depending on it. For example, environmental impacts of large-scale dams, such as changes in the flow regime, temperature and water chemistry, can lead to a loss of the fish, mammal and bird populations, affecting the livelihoods of local communities [28]. 
Community acceptance is therefore a multidimensional concept that is difficult to grasp using a single definition. However, it can be summarised as the approval of an act and the willingness to work towards its perpetuation for the future. The sustainability of energy projects largely depends on the degree of acceptance of its host population. Further, such acceptance will be stronger if participants perceive that the projects contribute to the enhancement of their lives and livelihoods, particularly in rural communities of developing countries where resources are scarce and living conditions are tough $[2,29,30]$. Acceptance may in fact improve the appropriation of technology and its sustainability in the future, which can only be achieved through people, their motivation to take care of the technology, their interest to understand it and their commitment to make it possible [31]. The lack of consideration of this concept by policy and decision-makers may be a determinant for the failure of a renewable energy project. People's acceptance must be considered in order to have a positive impact upon communities and provide a sustainable solution in time.

All of the factors highlighted above show different but important angles of community acceptance, viewed mainly from the perspective of the developer. However, we argue that community acceptance has yet to be viewed from the perspective of the communities, particularly with respect to how RES can transform people's livelihoods. In other words, we provide capacity for a framework where communities and their livelihoods are at the centre of social acceptance. Cherni et al. [2] advocate viewing the provision of energy in rural communities through the lens of the sustainable livelihoods (SL) framework, particularly the five assets, in order to reflect upon its true impacts on a given community (see also [23]). In the next section, we explore the sustainable livelihoods framework and discuss its main features.

\section{The Sustainable Livelihoods Framework}

It is known that humans have certain basic needs to fulfil in order to live and progress. The means they have at hand to sustain themselves and fulfil such basic needs are known as livelihoods. A livelihood is a concept that refers to all of the capabilities, assets and activities required for living. The sustainable livelihoods framework, created by the British Department for International Development (DFID), is a particular people-centric approach that aims to help organizations understand the real dimensions of poverty within rural communities, beyond the economic perspective. The SL framework acknowledges that rural communities own assets or capitals, and that the overall aim of any intervention must ensure their sustainability (see, e.g., [32-36]). Thus, when community intervention may occur, for instance, through the provision of energy, it is vital to anticipate how the intervention could affect people's assets and to think of strategies related to how to act and make the most of the intervention (see [37-39]).

The SL framework has five dimensions (see Figure 1): the vulnerability context, livelihood assets, transforming structures and processes, livelihood strategies and outcomes. The vulnerability context refers to those external uncontrollable factors that influence people's assets and may contribute to the occurrence of poverty. Livelihood assets or capitals are the fundamental building blocks of any community and they have been divided into five main categories: physical (e.g., such as houses, roads, schools, energy installations); financial (e.g., wages, savings, credits); natural (e.g., water, land, flora, wind, air quality); social (e.g., social networks, community organizations and affiliations); and human (education, health, skills, knowledge). These assets help us to assess the current living conditions in a given community and to realise the impact an external intervention could have on those living conditions in the future. Hence, the SL framework conceptualises poverty as a multidimensional factor that goes beyond the lack of income and includes people's access (or lack thereof) to those five assets. The transforming structures and processes part refers to the organizations and procedures needed to safeguard people's assets and to ensure access to these assets. Finally, livelihood strategies and outcomes refer to any practical intervention (e.g., a RES project) that is offered to further increase people's assets and achieve ultimate goals, such as increase well-being or reduce vulnerability [34]. 
The SL framework has proven to be a useful approach for understanding the effect of external interventions on rural communities, as it emphasizes the multiple factors that may affect their livelihoods [34]. Thus far, the framework has been mainly employed to assess poverty reduction in areas related to agriculture and has also been used in energy provision [1-3,23]. Here, we argue that the SL framework could be an appropriate lens to view the factors that drive sustainability and community acceptance and to explore the reasons why some energy projects may, or may not, be welcomed in a rural community. The provision of electricity is a common livelihood strategy that could have both positive and negative consequences for people's assets and their vulnerability context, and the perception of those consequences may divert the acceptance of projects. In the next section, we discuss how systems thinking could help us integrate our learning from the literature on RES acceptance, using the SL framework, in a systemic manner and why this would be desirable.

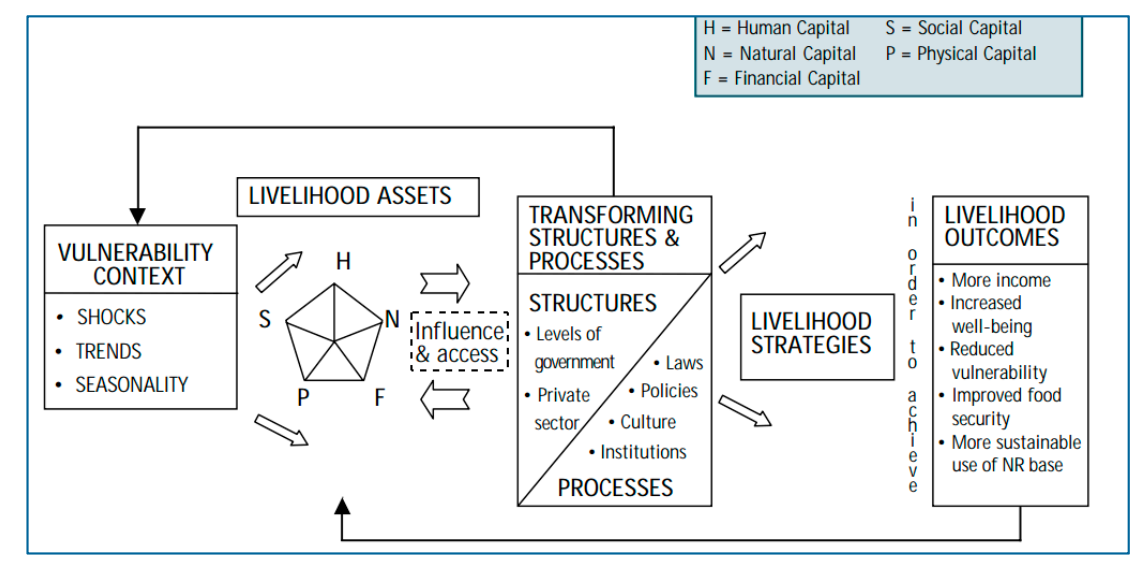

Figure 1. The sustainable livelihoods framework (source: DFID (British Department for International Development) [34]).

\section{Research Methodology: A Systems Thinking Perspective}

As discussed earlier, RES projects influence the livelihoods of rural communities at different levels, i.e., economically, socially, environmentally, etc. The interaction and interdependency of all of these factors results in considerable complexity that affects people's perceptions of the benefits and drawbacks of projects, which ultimately leads to their acceptance or rejection. Understanding the dynamic and systemic nature of this phenomenon is important to increase the possibility of implementing renewable energy systems that contribute to the growth and development of rural communities in the future (see [21,22]). Systems thinking, particularly causal-loop diagrams, have been advocated as an appropriate way to represent the systematic nature within different human phenomena related to sustainable development (e.g., [40-49]).

A causal-loop diagram (CLD) is a useful tool for representing and capturing mental models or hypotheses related to the feedback structure of a system [41]. The benefit of a causal-loop diagram is that it helps to represent the cause-and-effect relationship between two or more factors or variables and to unveil resulting feedback loops, which together form the causal structure of the system. This so-called causal structure can be used to identify the reasons why a particular system has a particular dynamic behaviour [50-53].

A causal diagram consists of variables connected by arrows (causal links) that denote the causal influences on such variables. Each link is assigned a polarity, which can be either positive $(+)$ or negative (-), indicating how the dependent variable changes when the independent variable changes (assuming all other variables are constant). A positive link means that the dependent variable moves in the same direction as the independent variable. By contrast, a negative link indicates that the independent and dependent variables move in opposite directions [41]. In addition, important loops are highlighted in the resulting diagram with a loop identifier, which serves to show whether the loop 
is a positive (reinforcing: $\mathrm{R}$ ) or negative (balancing: B) feedback [53]. For some arrows, there is a delay mark $(\mathrm{I} I)$, which means that the impact of the variables is not immediate and takes place in the long run. Finally, it is important to note that link polarities only describe the structure of the system and not the magnitude or behaviour of the variables per se [41].

We followed the principles of causal-loop diagrams to inductively analyse the literature reviewed with respect to the sustainability and acceptance of RES projects. Such principles helped us to make sense of our qualitative data (i.e., the papers reviewed). Systems thinking tools have been employed before to assist researchers in their analysis of the content and structure of qualitative data, both primary (originating from interviews) and secondary (originating from documents) [54]. Here, a literature review on sustainability and community acceptance of RES was conducted to identify the main factors that appear to play a role in slowing down or speeding up the implementation process of renewable energy projects. We searched for papers using various databases (e.g., Science Direct; JSTOR; Scopus; Google scholar) and combinations of keywords, such as: "community acceptance", "social acceptance", "rural energization", "energy and poverty", "renewable energy and community development", "sustainable development" and "sustainability of renewable energy". A total of 68 papers were analysed. From there, we were able to identify 19 main factors that were mentioned as having either a direct or an indirect effect on the acceptance of RES projects. In addition, some supporting factors were also included during the development of the causal-loop diagrams to preserve the logic of the diagrams and the story. Table A1 depicts a table with the key factors identified, the papers that contained these factors and excerpts of text that exemplify the causal connections with community acceptance or other factors.

The construction of the causal-loop diagrams took place as follows. We started by highlighting the factors that appeared in the various journal papers reviewed (more than three). Then, we used the SL framework, mainly the five livelihood assets or capitals, to classify the factors identified. This was not a pigeonhole process where each factor was assigned to one asset at a time since factors could cross boundaries between assets. Subsequently, we reviewed the papers again, highlighting potential cause-and-effect relationships and we framed them within the boundaries of the five livelihood capitals. As a result, we constructed five causal-loop diagrams, one for each asset. The diagrams were discussed and double-checked in terms of their systemic logic and consistency with the literature. The next section shows in detail the causal-loop diagrams derived from the analysis described above, along with a full description of their logic and particular examples of cases.

\section{Causal-Loop Diagrams Related to the Acceptance of RES Projects}

This section presents five causal-loop diagrams that show the factors that appear to predominantly influence the sustainability and acceptance of RES projects by rural communities (see Table A1). The diagrams were developed within the boundaries of five different livelihood capitals: social, human, physical, natural and financial. As stated above, secondary data were employed to facilitate the construction of the diagrams, particularly the main findings presented in different papers published in scientific journals concerning the acceptance of RES projects.

\subsection{Social Capital}

Social capital is understood to be the sum of positive relationships and social ties that exist among the members of a community or a group. Research shows that networks not only increase people's trust and their ability to work together but also facilitate the embracement of mutually agreed decisions [34]. The UN Commission on Sustainable Development considers that social capital is one of the most complex dimensions of sustainability because its state of development heavily depends on the level of development of other livelihood capitals [55,56].

Research has also found that the advent of new technologies in a rural community creates clashes between old routines and ancient practices and the new habits that come with the incorporation of such technologies [20]. These changes or clashes can be either positive or negative, depending on the 
culture and the level of stress experienced by people (see B1 in Figure 2). Maruyama et al. [57] analysed the socio-economic dynamics that originated from the arrival of renewable energy technologies in Japanese communities. The authors found that RES projects can change people's perception of the rules of risk-benefit distribution and the roles that different actors play in society, which is a process termed "social innovation". As mentioned in Section 3, participation in decision-making increases perceptions of fairness, which in turn, influences how people perceive the legitimacy and benefit of a project [17]. When changes in the risk-benefit distribution take place due to deviations in traditional routines, people's fairness perception also changes, influencing the social networks of a community [58]. As a result, the acceptance of the technology is manifested in people's level of commitment and their desire to participate in and sustain the technology [59] (see also B1 in Figure 2).

In this regard, Kaygusuz [60] discovered that renewable energy projects are capable of changing the roles of women in society, particularly in communities where they are mainly responsible for cooking and feeding their families. The challenging and time-consuming task of collecting and managing traditional fuels, mainly wood, to conduct these activities has been widely viewed as women's responsibility. In India's rural villages, women walk, on average, $30 \mathrm{~km}$ per month and take approximately $3 \mathrm{~h}$ per trip for wood collection at high altitudes and over unsteady terrains, which has negative consequences for their health (human capital) [61,62]. Rural energy access through RES changes this situation by allowing women to meet their basic needs through cooking, lighting and heating as well as have more leisure time for other social interactions [63]. These changes are usually seen as positive and, therefore, community members usually accept the technology.

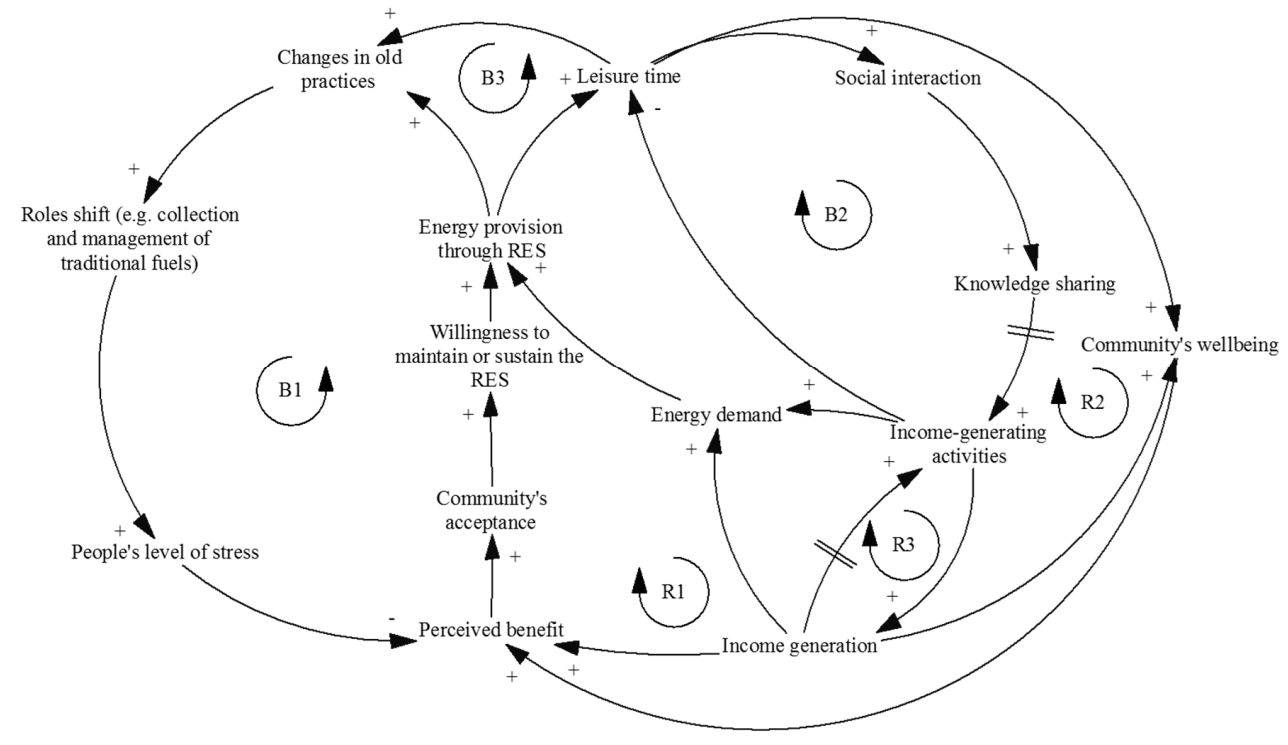

Figure 2. Causal-loop diagram for the social capital.

Changes in the role of women in these societies create tension and stress as well as opportunities for them to engage with other members of their communities in productive ways $[5,62,64]$ (see R1 and $\mathrm{R} 2$ in Figure 2). Alternative social engagements usually lead to the sharing of knowledge (see $[60,62]$ ) and the creation of new ideas for income generation [65] (see B2 and R3 in Figure 2). Both income generation and involvement in income-generating activities further increase the demand for energy, which can be supplied through RES. Figure 2 shows the causal-loop diagram with the factors discussed above within the boundaries of the social capital.

\subsection{Human Capital}

Human capital refers to all of the means and abilities an individual has to be productive and to achieve his/her livelihood objectives by him/herself [35]. Hence, the skills, knowledge and health 
conditions of an individual form his/her human capital. Having access to higher quality education, technologies for productivity and information and systems for supporting health and nutrition can therefore enhance human capital. The lack of energy, electricity in particular, makes the provision of health services, education and industrial activities difficult $[20,66]$.

Providing communities longer hours of lighting can lead to an increase in education because people could spend more hours at night studying, and schools could invest in internet and computers to gain access to global information [65,67-69] (See R4 and R6 in Figure 3). This would allow them to be more competitive and productive and improve their income in the long run, which could be reinvested in education $[69,70]$. The sustainability of RES projects can also receive the benefits of education because education can empower community inhabitants, making them more knowledgeable of the benefits of the technology and more able to operate and maintain the technologies themselves [71,72]. By having more knowledge about the benefits of RES, communities are more likely to accept and embrace them [73-78]. Educating the target population about the benefits of RES is vital to counteract any negative preconceptions or scepticism associated with the use of these technologies [79].

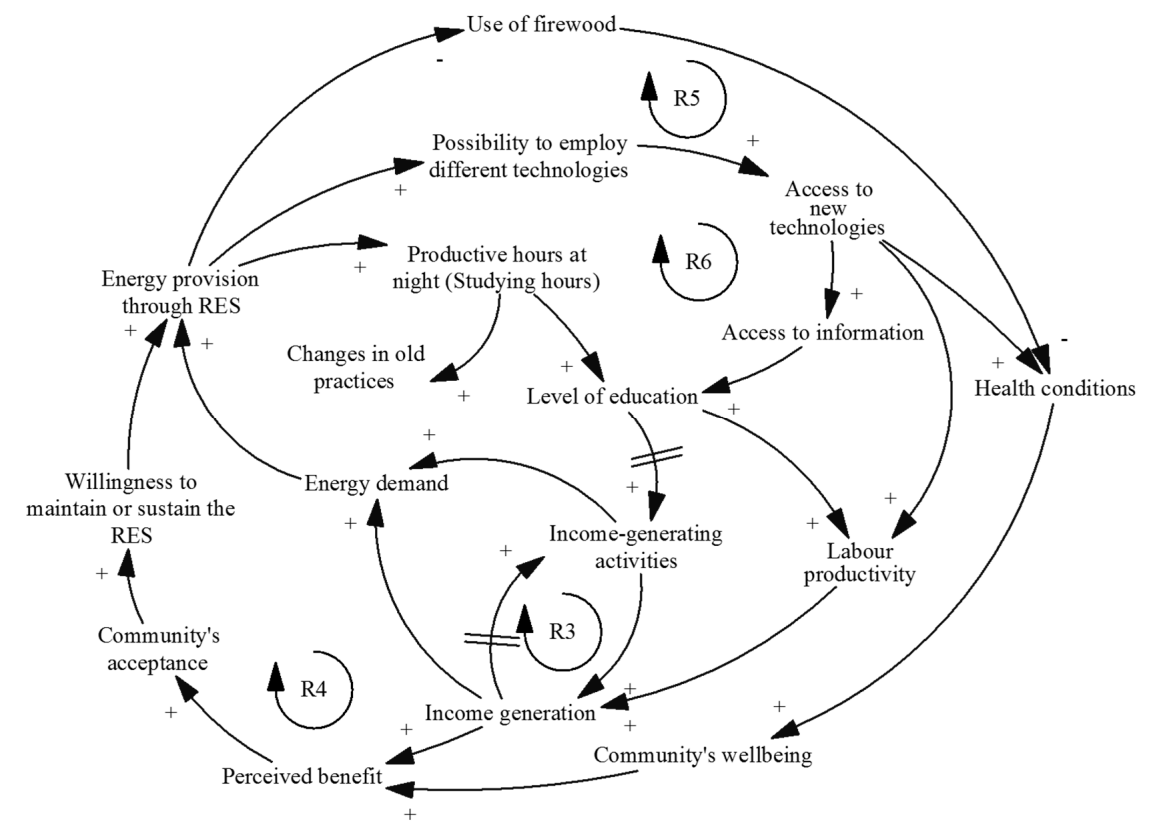

Figure 3. Causal-loop diagram for the human capital.

In terms of health, it is well-known that issues such as global warming, acid rain and other pollution effects can be prevented by the use of RES. In addition to such large-scale effects, which are not noticeable by community inhabitants on a daily basis, the health component of the human capital can be improved when vaccines are refrigerated and when indoor air pollution is reduced when coal- and wood-based stoves are replaced by solar stoves $[5,65,68,71,80]$. The use of firewood and biomass inside households is a major health threat due to the smoke produced, which causes respiratory infections in the long term [79] (see R5 in Figure 3). Therefore, RES can improve the health conditions of people in this regard, allowing rural communities to access health technologies that require electricity in order to function, as well as providing access to drinkable water and sanitation services. For example, in Colombia, the population of San Jose Cravo Norte required an energy solution that could supply electricity $24 \mathrm{~h}$ a day for the refrigeration of vaccines in a local health centre. By providing renewable energy technologies to this community, their access to medicine has increased and, consequently, an improvement in their health conditions has been noted [2]. Figure 3 shows the causal-loop diagram and the factors that appear to have an effect on the acceptance of RES projects within the boundaries of the human capital. 


\subsection{Physical Capital}

Physical capital refers to all infrastructure and technology available to communities to support their livelihoods. This includes changes in the physical environment (infrastructure) and the tools or equipment that may make life easier and more productive for people [33,34]. Research shows that lack of basic infrastructure makes the possibility of having quality education, health and income generation more difficult because it constrains the capacity of communities to develop and grow [81]. More specifically, the lack of materials, technologies and equipment reduces the levels of productivity in any community, affecting its competitiveness, ability to create revenue and wellbeing [82,83]. On the contrary, having access to energy services not only allows the utilization of technologies that may facilitate life in general but also makes the community more attractive for public and private investors to further contribute to the development of the community $[22,84]$ (see R7 in Figure 4). Further investments would incentivise the creation of new RES projects that would in turn enhance the village's infrastructure, making it more competitive for the future [22]. Communities with good levels of physical assets provide inhabitants access to secure buildings, adequate water supply and clean and affordable energy [64]. Therefore, the physical capital of a community determines the extent to which other livelihood assets (human and social) could increase. Consequently, the greater the benefits for local communities, the greater the attractiveness of rural areas, and the greater the possibilities of the social acceptance of the projects [59].

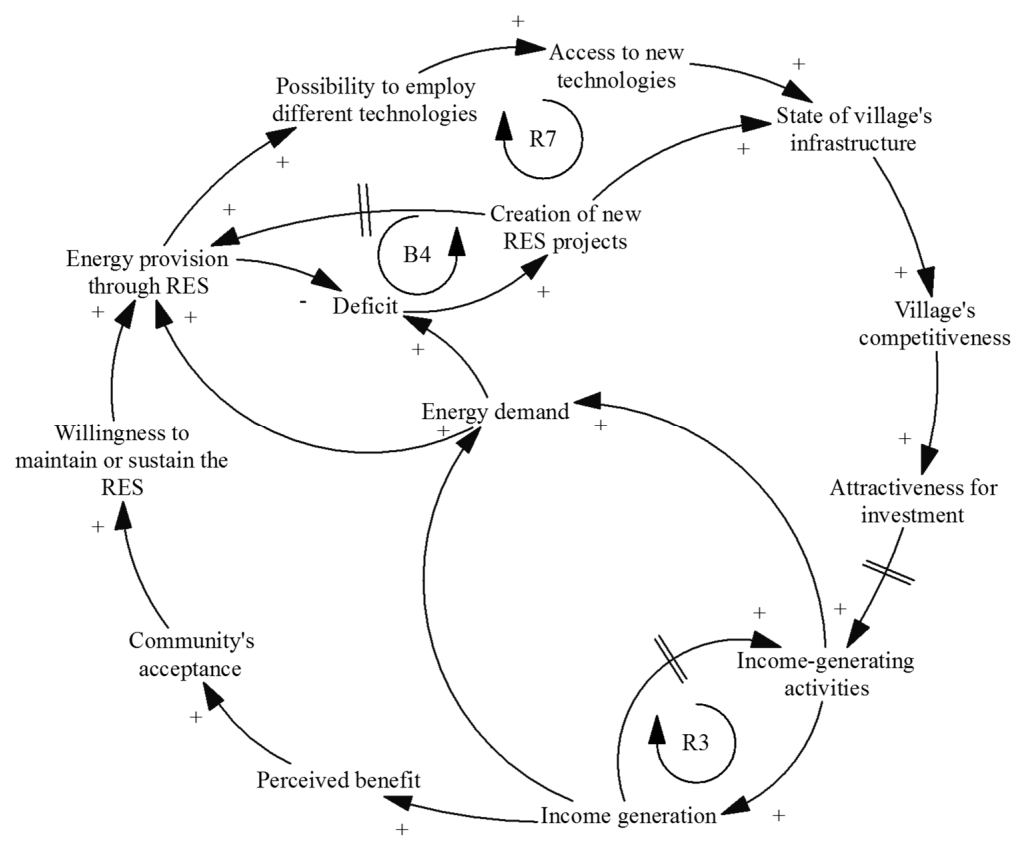

Figure 4. Causal-loop diagram for the physical capital.

\subsection{Natural Capital}

Natural capital refers to the quality of the natural environment that surrounds a community. This includes the quality of the air inhabitants breathe, the quality of the water they drink, the productivity and size of their land and the biodiversity they have at hand in general. It is usually the case that the effect of any human intervention on the environment is adverse with respect to the natural capital, particularly if such intervention seeks the development of the community [71]. The natural capital can be affected by the adoption of RES in both direct and indirect ways. For example, the construction of a free-flow spillway, which modifies the course and shape of a river, has been seen by some as a depletion of this asset [27]. In addition, as discussed earlier, wind turbines can cause noise, interfere with the aesthetics of the landscape and threaten fauna. This type of direct intrusion 
on the environment has been an obstacle for the acceptance of RES in communities $[9,85]$. On the other hand, when an RES solution contributes successfully to the development of a given community, its population grows, its industries flourish and its infrastructure increases. This industrialization dynamic also contributes to the depletion of the natural capital (see, e.g., [86-89] (see B5 in Figure 5).

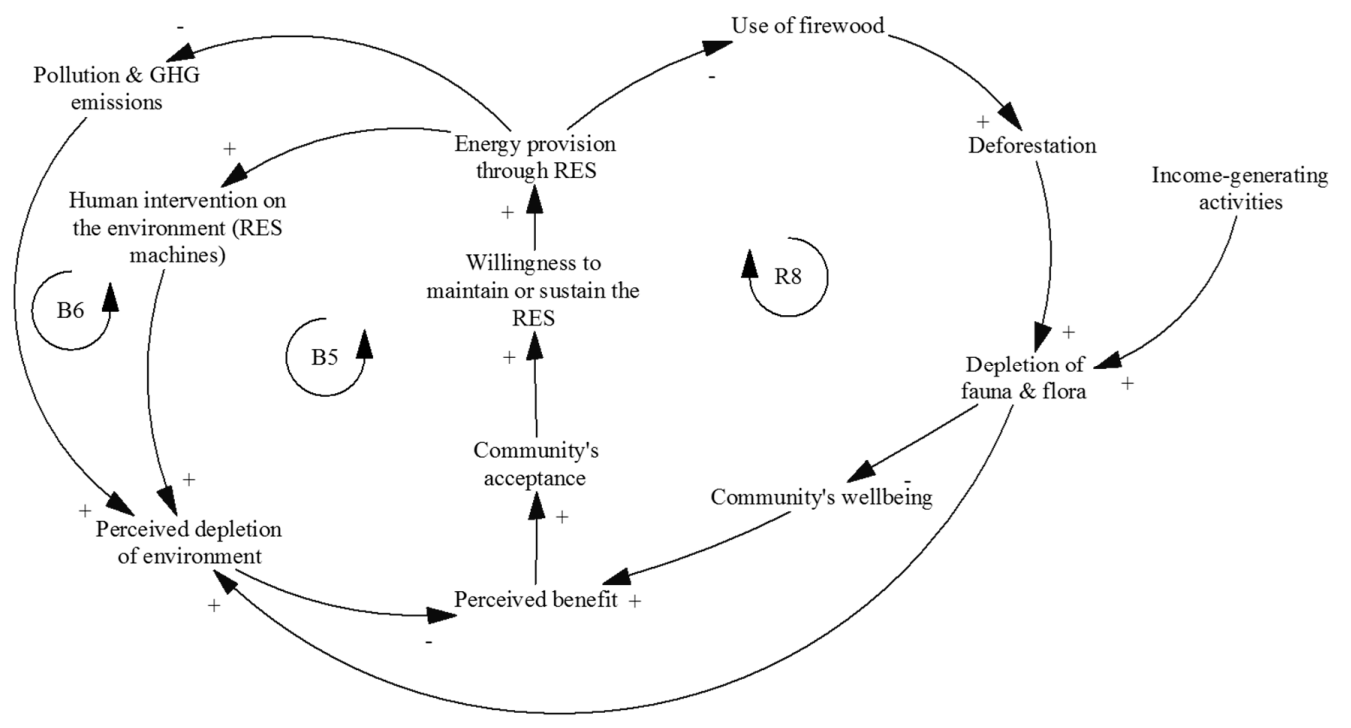

Figure 5. Causal-loop diagram for the natural capital.

However, changing traditional sources of energy, such as wood and fossil fuels, to renewable sources has some positive impacts on the natural capital, mainly regarding the reduction of deforestation, the protection of fauna and flora and the decrease in local and household air pollution $[68,80]$ (see B6 and R8 in Figure 5). As a result, the European Union and some governments have adopted targets for the expanded use of renewable energies to improve energy security, reduce GHG emissions and achieve the competitiveness of the European economies [90]. This type of argument could be employed as a strategy to lessen concerns of energy-related environmental impacts and therefore achieve better community acceptance [26,91].

Figure 5 depicts the causal-loop diagram with the factors affecting the natural capital and their relationship with community acceptance.

\subsection{Financial Capital}

Financial capital refers to all monetary resources a community has to achieve livelihood objectives. These can be in the form of available stocks, which refer to credits, regular inflows of money, or transfers from the state, such as pensions. As stressed earlier, renewable energy technologies can contribute to possible income-generating activities of households (see R7 in Figure 6). Scholars, such as Inglesi-Lotz [92] and Sadorsky [93], have shown that there is a high correlation between the economic performance of a country and the implementation of RES in emerging economies. However, the productive side-effect of RES should not be assumed because communities also require access to financial services (e.g., credits) in order to break the poverty cycle and enable their people to invest in productive technologies that are not easily attainable to them [94,95]. Not having access to financial resources and credits can be a critical factor related to the adoption of any capital-intensive business in rural areas and the maintenance of an RES solution [96]. In such cases, experts on clean energy have highlighted the need to set up payment models that minimize the risk of default, for example by establishing payments during harvest seasons for the energy technologies and other consumer products [97] (see R10 in Figure 6). 
The financial sustainability of RES interventions is often determined by the existence of income-generating activities (businesses) in the communities. Then, if communities are not capable of breaking the poverty cycle, the RES intervention may not survive either because the high costs associated with its installation and maintenance may be seen as an unaffordable and unnecessary expense [79,98]. Energy services are better welcomed when people perceive opportunities of income gains or productive uses. Therefore, inciting the poor to use energy services productively is an effective strategy in spreading energy access [94,99-101] and providing greater benefits to the rural poor $[66,102]$.

In this regard, Painuly [98] highlighted the following as barriers to the implementation of renewable energy: the lack of institutions and mechanisms to disseminate information, the lack of legal and regulatory frameworks to incentivise RES and the lack of synergy between the government and other supporting institutions. In addition, it has been argued that problems in realising financial incentives and credit access are barriers linked to the low participation of the private sector in the rural energy market. Consequently, if politicians provide incentives and subsidies, the initial investments of RES would be lower, becoming more attractive for stakeholders to develop the needed infrastructure. In this regard, Biswas et al. [66] proposed a mechanism to form cooperatives that are perceived less risky to being granted financial support and credits from banks and large non-governmental organizations (NGOs). This would enable the landless and the more marginal rural peasants to have ownership of RES-related businesses.

In addition, revenues for communities from a renewable energy project can also be perceived during its construction phase with the purchase of materials, equipment and the payment of local wages (see R9 in Figure 6). Nevertheless, negative economic effects may appear due to the displacement of trade based on the former energy supply [71] (see B7 in Figure 6).

In summary, we argue that the implementation of RES in rural areas of developing nations requires the existence of organizations and institutions that can provide financial support to the rural poor in order to enhance the local economy and increase the chances of survival of the projects.

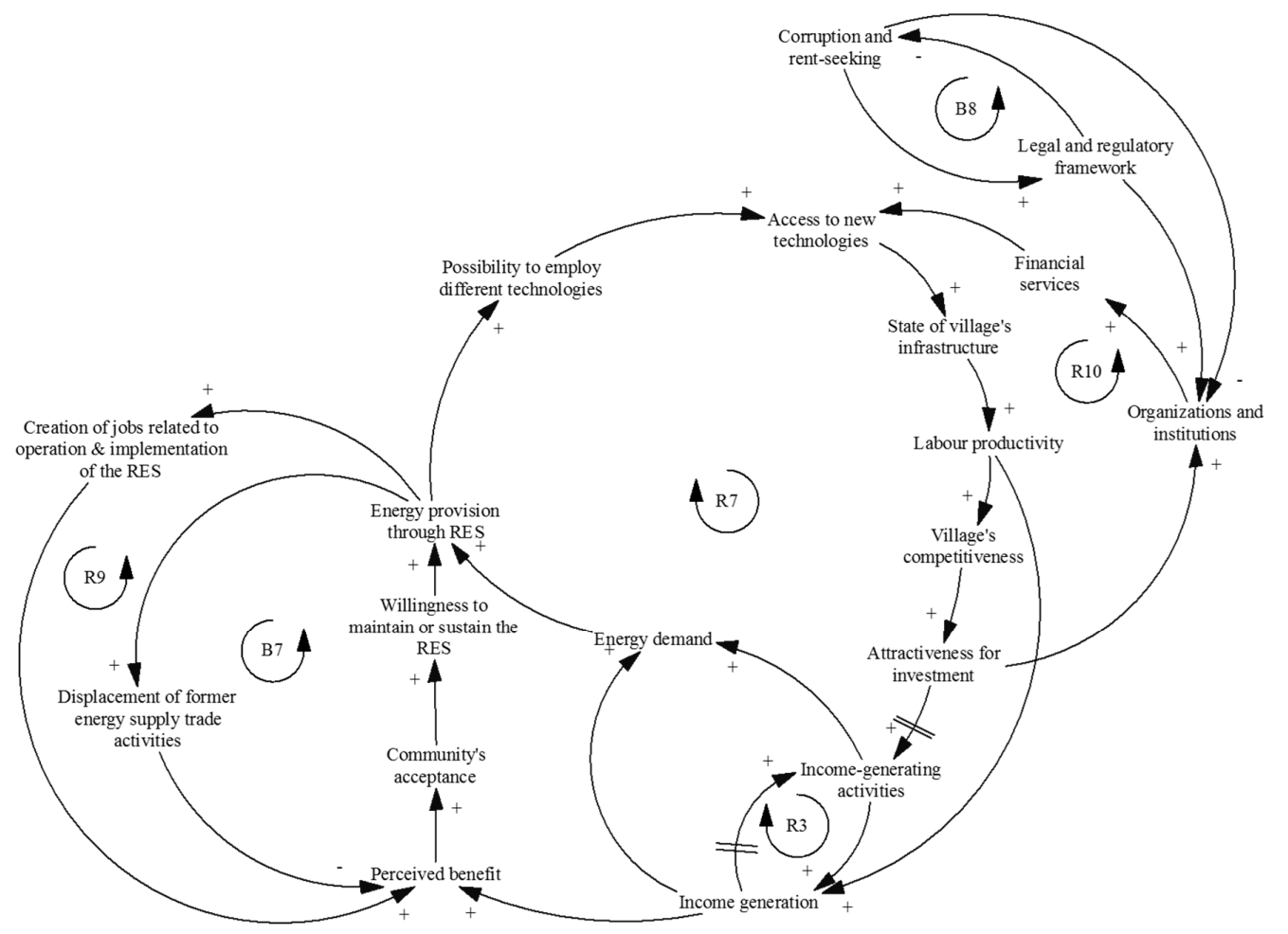

Figure 6. Causal-loop diagram for the financial capital. 
The political dimension is not part of the SL framework. However, it is mandatory to consider it since the powerful actors involved in the development of environmental policies also play a key role in incentivizing the implementation of RES. Fredriksson and Svensson [103] studied the effects of corruption and political instability on the implementation of environmental policies (see B8 in Figure 6). Their model explains how corruption reduces the "stringency" (i.e., the efficiency of implementation) of environmental regulations. Lopez and Mitra [104] also reached the same conclusion from the point of view of the environmental consequences of government corruption and rent-seeking. Government ideology is another factor that potentially affects the environmental quality and the stringency of energy policies [105]. Pietrosemoli and Rodríguez [83] show, as an example, the case of Venezuela, which has great potential for renewable energy projects, similar to most Latin American countries. However, due to the pre-eminence of politics over decisions, foreign currency restrictions and restrictive labour regulations make it harder to complete projects. Pansera [106] also highlights Bolivia's potential in terms of sun, wind and hydroelectric energy production but notes the lack of existing policies to foster the use and production of energy. This shows the importance of the political dimension for the sustainability of RES projects and demonstrates that a poor political scheme can lead to the failure of an environmental policy.

\section{Discussion}

The last section showed that livelihood consists of a variety of both market-oriented and non-market-oriented activities adopted by poor households. The adoption of these strategies aims to sustain and improve their situation with the use of their stock of capital assets. Both material (physical and financial) and nonmaterial (human and social) assets contribute to the reduction in poverty, which can be achieved with the accumulation of the assets over time, and in the same way can lead to better living standards [60]. Understanding the relationship between a community's assets and the potential outcomes resulting from the implementation of renewable energy projects is key for learning how to boost the level of acceptance of projects by communities and to determine sustainability indicators and the survival of projects over the long term.

Figure 7 shows the overall causal-loop diagram, which combines the diagrams discussed above within the boundaries of the five SL capitals. The diagram represents our learning of the main relationships and feedback loops that appear to exist among the key factors identified from the literature reviewed, and how these influence the acceptance of a renewable energy project by a community and its subsequent sustainability.

As mentioned before, the diagram also indicates potential points of intervention for an RES project. The literature reviewed and the construction of the causal-loop diagram show that any external intervention within a rural community needs to be seen holistically and comprehensively, where multiple dimensions of the community are taken into consideration. For example, decision makers and energy planners must consider how the technology may change the traditions and practices within a community and anticipate its effects. Issues such as how the roles of women in the community may change due to the arrival of a new technology or what elements of nature are untouchable should be taken into consideration, because changes that may be seen as positive by outsiders could be perceived as negative by community inhabitants. This creates tensions and stress in the community, leading to the rejection of the projects. It is important to be aware of the cultural differences and to investigate how willing the community is to adapt to the new situation. Ignoring these factors would lead to the failure of any given solution. As an example, let us take the case of La Guajira, along the north coast of Colombia, where local indigenous communities are particularly reluctant to accept modern and western traditions. As a result, hundreds of children die there every year, partly because their parents forbid them to be treated with traditional western medicines and procedures, instead preferring their ancient medicines and prayer rituals. 


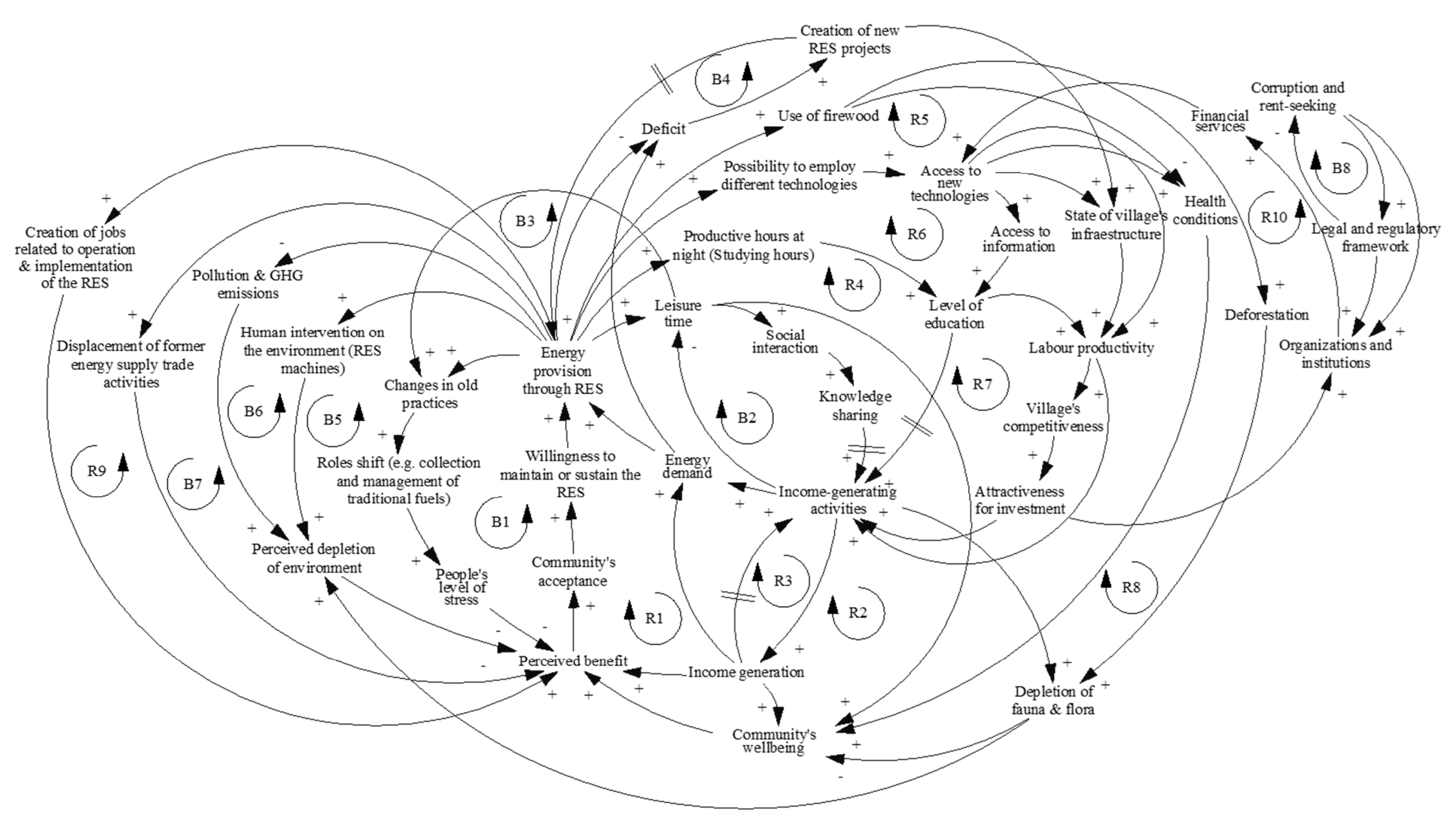

Figure 7. Causal-loop diagram for all SL capitals. 
Throughout our literature review and the construction of the diagrams, we also learned that it is important to involve the communities, to inform them of the benefits of the renewable technologies, and to show them the dangers of traditional practices, such as cooking with firewood indoors. Education is important to improve the livelihood of communities and ensure their acceptance of the projects. It also entails teaching communities how to take advantage of the technology, how other technologies that use electricity may complement and enhance their livelihoods and how these appliances could be used to create income-generation initiatives. Finally, as discussed earlier, the role of institutions and governmental organisations is crucial to facilitate the conditions needed to boost the local economy to provide access to financial services, create a local energy market and increase the likelihood that these projects will be sustainable.

\section{Conclusions}

Renewable energy has been advocated as an ideal way to supply the energy demanded by an increasing population in a sustainable way. It is considered an important resource to improve the difficult situation of over two billion people [107], mostly located in rural zones, where access to traditional energy is limited or non-existent. Natural resources are fundamental to expand this process worldwide. Depending on the geographical conditions of a country, there are more or fewer natural resources available to produce renewable energy. However, natural resources and geographical conditions are not the only important factors needed to successfully implement these energies. Community acceptance plays a major role to ensure access to affordable, reliable, sustainable and modern energy for all, an objective included in the new global sustainable development agenda [108].

While acceptance has been recognized as an important factor driving the success of RES projects, in this paper, we sought to address the need for a systemic view of community acceptance of RES projects. Through the lens of the SL framework and based on an extensive literature review, we developed a causal-loop diagram of the relationships leading to improved livelihoods of rural communities in developing countries.

We believe our perspective offers a concrete and comprehensive view of acceptance and sustainability of RES projects. By considering the perspective of the livelihoods of communities, we were able to identify the key barriers that influence the sustainability of projects and to determine what is needed to increase the acceptance of renewable energy technologies. We hope this work aids in understanding the most important variables that should be considered at the time of implementation and will help future energy planners and decision makers gain greater acceptance by the community with respect to renewable energy, allowing the effective sustainability of projects.

Acknowledgments: Universidad Icesi funded this work through its inner research-funding programme.

Author Contributions: Ana María González performed a first review and analysis of the literature and contributed to the writing of the manuscript. Harrison Sandoval performed a second review and analysis of the literature, helped with the construction of the causal-loop diagrams, and contributed to the writing of the manuscript. Pilar Acosta helped to define the terms community acceptance and sustainability, contributed to the writing of the manuscript, and provided useful advice revising the causal-loop diagrams. Felipe Henao proposed the main structure of this study, contributed to the construction of the causal-loop diagrams, and helped with the writing of the manuscript. All authors provided useful advice throughout the project development and revised and approved the final manuscript.

Conflicts of Interest: The authors declare no conflict of interest. 


\section{Appendix A}

Table A1. List of Factors Connected to Rural Community Acceptance.

\begin{tabular}{|c|c|c|}
\hline Factor & Articles & Excerpts of Potential Causal Links \\
\hline $\begin{array}{l}\text { Roles shift/Changes in old } \\
\text { practices }\end{array}$ & {$[20,57,60-62,64,71]$} & $\begin{array}{l}\text { "Gender considerations come into play because in many developing countries, the current lack of energy in rural areas has a } \\
\text { disproportionate impact on women. They are the ones primarily responsible for collecting and managing traditional biomass } \\
\text { fuels" [60] (p. 945). "Renewable energy may be in a unique position to promote a paradigm shift in agricultural production, } \\
\text { by making possible irrigation and associated modern technology and practices" [60] (p. 943). }\end{array}$ \\
\hline Leisure time & {$[60,62,63]$} & $\begin{array}{l}\text { "There are alternative energy technologies (AETs) that offer significant potential in terms of reducing women's drudgery, } \\
\text { improving health conditions, freeing time for involvement in income-generating, social, and community development activities } \\
\text { for their self-enhancement and empowerment" [62] (p. 407). }\end{array}$ \\
\hline $\begin{array}{l}\text { Social Interaction/ } \\
\text { Knowledge sharing }\end{array}$ & {$[60,62,63,109]$} & $\begin{array}{l}\text { "Such technologies have been able to/ ... / provide opportunities for women to be involved in some social and economic } \\
\text { activities" [62] (p. 409). }\end{array}$ \\
\hline $\begin{array}{l}\text { Income-generating } \\
\text { activities/involvement in } \\
\text { other productive activities }\end{array}$ & {$[3,5,57,60-62,65,71,80,83,102]$} & $\begin{array}{l}\text { "In many countries, poverty is prolonged particularly by the unsustainable collection of biomass and its use in traditional, } \\
\text { inefficient stoves./ ... / It requires large amounts of time for fuel gathering-reducing the time available for other productive } \\
\text { activities, such as farming and education" [5] (p. 1119). "In addition, women are the main producers of food crops in many areas. } \\
\text { If these women could grow oil-producing crops, sell them for income, and also use the oil for motorized power, electricity } \\
\text { generation, household activities and profitable enterprises, this could open up exciting new opportunities for local economic } \\
\text { development. Studies have shown that women can also profit by establishing and sharing in bioenergy processing } \\
\text { operations" [60] (p. 945). }\end{array}$ \\
\hline Productive hours at night & {$[5,68-70]$} & $\begin{array}{l}\text { "Modern energy services enhance the life of the poor in countless ways. Electric light extends the day, providing extra hours for } \\
\text { reading and work" [5] (p. 1119). }\end{array}$ \\
\hline Health conditions & {$[2,3,5,8,62,65,68,70,71,79,80,109]$} & $\begin{array}{l}\text { "Traditional technologies have a negative impact on women's health due, for example, to the smoke from firewood and to their } \\
\text { heavy workload" [62] (p. 409). "Since the diesel generator had been removed and there was therefore no more noise and air } \\
\text { pollution from this source, an improvement in health could be expected" [109] (p. 652). }\end{array}$ \\
\hline $\begin{array}{l}\text { Possibility to employ } \\
\text { different technologies/ } \\
\text { access to new technologies }\end{array}$ & {$[65,67,98]$} & $\begin{array}{l}\text { "Renewable energy can play an important role in helping to meet basic energy needs in peri-urban zones and in rural areas, } \\
\text { through the use of modern technologies" [67] (p. 1). "Solar photovoltaics (PV) installed in the country are mainly in the rural areas } \\
\text { at service centres such as schools and hospitals as well as individual homes. In rural areas, PV is used for lighting, radio and } \\
\text { television" [67] (p. 29). }\end{array}$ \\
\hline Labour productivity & {$[20,62,68,70,83,94,99-102]$} & $\begin{array}{l}\text { "It would reduce the time and drudgery required for gathering firewood and other biomass resources-some of the saved time } \\
\text { could be used for other economically productive applications in the case of adults, and for education in the case of } \\
\text { children" [70] (p. 1370). }\end{array}$ \\
\hline Level of education & {$[3,5,68-70,73-78]$} & $\begin{array}{l}\text { "Among other benefits, access to electricity/ ... /extends the daily productive hours, allowing children to study in the evenings } \\
\text { and obtain a better education through the use of new technologies at schools" [69] (p. 275). }\end{array}$ \\
\hline
\end{tabular}


Table A1. Cont.

\begin{tabular}{|c|c|c|}
\hline Factor & Articles & Excerpts of Potential Causal Links \\
\hline $\begin{array}{l}\text { State of village's } \\
\text { infrastructure/Village's } \\
\text { competitiveness }\end{array}$ & {$[68,81-83]$} & $\begin{array}{l}\text { "Currently, the growing recognition of energy as part of the solutions for society needs to draw attention to the evolution of the } \\
\text { infrastructure projects related to energy production, distribution and use as a way to improve quality of life and to support } \\
\text { sustainable development. / ... / The availability of an adequate infrastructure for water, energy, roads, industry or } \\
\text { communications has been identified as a fundamental element for the productivity and competitiveness of nations. In fact, the } \\
\text { conditions of such infrastructure have an important effect over national costs, logistics and processes in general. They also have an } \\
\text { influence on population health and educational levels and may reduce income inequalities" [83] (p. 686). }\end{array}$ \\
\hline Attractiveness for investment & {$[5,22,59,83,84,110]$} & $\begin{array}{l}\text { "Therefore, the increased deployment of renewable sources as a means to improve the electricity access rate in less developing } \\
\text { economies largely hinges upon their ability to identify innovative mechanisms to attract both domestic and foreign capital and } \\
\text { increase financing" [110] (p. 2201). }\end{array}$ \\
\hline Energy demand & {$[5,21,22,79,90]$} & $\begin{array}{l}\text { "Energy plays an important role in human welfare. The dynamic hypothesis is: the more development, more energy } \\
\text { demand" [22] (p. 203). }\end{array}$ \\
\hline Deforestation & {$[5,60,68,80,110]$} & $\begin{array}{l}\text { "Similarly, the collection and burning of woody biomass can have effects on ground cover, and the burning of dung can affect the } \\
\text { level of nutrients being returned to the soil. However, the link between the energy uses of biomass and deforestation varies from } \\
\text { location to location" [60] (p. 946). }\end{array}$ \\
\hline $\begin{array}{l}\text { Human } \\
\text { intervention/Depletion of } \\
\text { fauna \& flora }\end{array}$ & {$[10-14,27,28,62,68,80,85-89]$} & $\begin{array}{l}\text { "Traditional firewood cooking causes faster depletion of biomass resources and adds to the women's working hours in collecting } \\
\text { firewood" [62] (p. 409). }\end{array}$ \\
\hline Pollution and GHG emissions & {$[26,65,70,71]$} & $\begin{array}{l}\text { "Many people are well aware that fossil fuels are a major contributor to environmental damage such as acid rain and global } \\
\text { warming. In addition, nuclear power is not seen as an acceptable alternative by many. Sources of renewable energy are generally } \\
\text { accepted as clean or environmentally friendly and this is a very strong motivating factor for some" [71] (p. 188). }\end{array}$ \\
\hline $\begin{array}{l}\text { Creation of jobs related to } \\
\text { operation and } \\
\text { implementation of RES }\end{array}$ & {$[59,65,68,71]$} & $\begin{array}{l}\text { "The development of renewable energy might contribute to the rural community in three different perspectives such as by } \\
\text { creating jobs, by creating local tax income from sold off energy and by reducing the costs of energy after the initial set up cost" [71] } \\
\text { (p. 186). "The creation of a few jobs may have a significant impact on isolated local communities with scarce development and } \\
\text { employment alternatives" [59] (p. 1330). }\end{array}$ \\
\hline Access to financial services & {$[66,96,97]$} & $\begin{array}{l}\text { "RETs could thus be selectively applied to various rural applications, potentially generating income, improving health and } \\
\text { educational quality, and increasing labour productivity. However, such potential benefits arising from RETs may be realised only } \\
\text { through a process that appropriately harnesses the social and financial context of village life. [66] (p. 336). Lack of capital is the } \\
\text { major constraint to such income-generating activities. Such activities (raising livestock, handicrafts, tailoring, etc.) that can be } \\
\text { facilitated by a micro-credit loan distribution system have already been found more applicable to rural women than to men in } \\
\text { rural Bangladesh" [66] (p. 337). }\end{array}$ \\
\hline $\begin{array}{l}\text { Organization and } \\
\text { institutions/legal } \\
\text { and regulatory } \\
\text { framework/Corruption } \\
\text { and Rent-seeking }\end{array}$ & {$[5,15,66,68,70,98,103,104,106,110,111]$} & $\begin{array}{l}\text { "Government agencies, non-governmental organizations (NGOs), development organizations and other actors have been } \\
\text { involved in a variety of programs to enhance-quantitatively and qualitatively-energy services for the poor" [70] (p. 1368). } \\
\text { "Several barriers that have prevented penetration of RETs have been listed in the literature. These include cost-effectiveness, } \\
\text { technical barriers, and market barriers such as inconsistent pricing structures, institutional, political and regulatory barriers, and } \\
\text { social and environmental barriers" [98] (p. 75). }\end{array}$ \\
\hline Community's acceptance & {$[2,8,9,17-20,25,26,29-31,58,71,91]$} & $\begin{array}{l}\text { "The acceptance of renewable energy is more likely if the community feels that its current supply is problematical. It may be that } \\
\text { the lifestyle changes mentioned above are wholly acceptable as they are already equivalent to or an improvement on the current } \\
\text { situation" [71] (p. 188). }\end{array}$ \\
\hline
\end{tabular}




\section{References}

1. United Nations Development Programme. Energy as a Tool for Sustainable Development; For ACP Countries; UNDP: New York, NY, USA, 1999.

2. Cherni, J.; Dyner, I.; Henao, F.; Jaramillo, P.; Smith, R. Energy supply for sustainable rural livelihoods. A multi-criteria decision-support system. Energy Policy 2007, 35, 1493-1504. [CrossRef]

3. Niu, S.; Jia, Y.; Wang, W.; He, R.; Hu, L.; Liu, Y. Electricity consumption and human development level: A comparative analysis based on panel data for 50 countries. Int. J. Electr. Power Energy Syst. 2013, 53, 338-347. [CrossRef]

4. Schmidt, J.; Cancella, R.; Pereira, A. An optimal mix of solar PV, wind and hydro power for a low-carbon electricity supply in Brazil. Renew. Energy 2016, 85, 137-147. [CrossRef]

5. Kaygusuz, K. Energy for sustainable development: A case of developing countries. Renew. Sustain. Energy Rev. 2012, 16, 1116-1126. [CrossRef]

6. Caspary, G. Gauging the future competitiveness of renewable energy in Colombia. Energy Econ. 2009, 31, 443-449. [CrossRef]

7. Iniyan, S.; Suganthi, L.; Jagadeesan, T.; Samuel, A. Reliability based socio economic optimal renewable energy model for India. Renew. Energy 2000, 19, 291-297. [CrossRef]

8. Wüstenhagen, R.; Wolsink, M.; Bürer, M. Social acceptance of renewable energy innovation: An introduction to the concept. Energy Policy 2007, 35, 2683-2691. [CrossRef]

9. D'Souza, C.; Yiridoe, K. Social acceptance of wind energy development and planning in rural communities of Australia: A consumer analysis. Energy Policy 2014, 74, 262-270. [CrossRef]

10. Valencia, A. Effects of Electricity Market Regulations on the Promotion of Non-Conventional Energy Sources in Colombia Power's Mix. Int. J. Public Policy 2009, 4, 76-99. [CrossRef]

11. Schilling, M.; Esmundo, M. Technology S-curves in renewable energy alternatives: Analysis and implications for industry and government. Energy Policy 2009, 37, 1767-1781. [CrossRef]

12. Rybach, L. Geothermal energy: Sustainability and the environment. Geothermics 2003, 32, 463-470. [CrossRef]

13. Williamson, A. Sustainable Energy in Cambodia: Status and Assessment of the Potential for Clean Development Mechanism Project; Ministry of Environment: Nom Pen, Cambodia, 2004.

14. Singh, J.; Gu, S. Biomass conversion to energy in India-A critique. Renew. Sustain. Energy Rev. 2010, 14, 1367-1378. [CrossRef]

15. Jobert, A.; Laborgne, P.; Mimler, S. Local acceptance of wind energy: Factors of success identified in French and German case studies. Energy Policy 2007, 35, 2751-2760. [CrossRef]

16. Kaldellis, J. Social attitude towards wind energy applications in Greece. Energy Policy 2005, 33, $595-602$. [CrossRef]

17. Gross, C. Community perspectives of wind energy in Australia: The application of a justice and community fairness framework to increase social acceptance. Energy Policy 2007, 35, 2727-2736. [CrossRef]

18. Huijts, N.; Molin, E.; Steg, L. Psychological factors influencing sustainable energy technology acceptance: A review-based comprehensive framework. Renew. Sustain. Energy Rev. 2012, 16, 525-531. [CrossRef]

19. Zoellner, J.; Schweizer-Ries, P.; Wemheuer, C. Public acceptance of renewable energies: Results from case studies in Germany. Energy Policy 2008, 36, 4136-4141. [CrossRef]

20. García, V.; Bartolomé, M. Rural electrification systems based on renewable energy: The social dimensions of an innovative technology. Technol. Soc. 2010, 32, 303-311. [CrossRef]

21. Dyner, I.; Alvarez, C.; Cherni, J. Energy contribution to sustainable rural livelihoods in developing countries: A system dynamics approach. In Proceedings of the 23rd International Conference of the System Dynamics Society, Boston, MA, USA, 17-21 July 2005.

22. Franco, C.; Dyner, I.; Hoyos, S. Contribution of the energy at development of islated communities in not interconnected zones: A case of application of the systems dynamics and sustainable livelihoods in the colombian southwest. DYNA 2008, 75, 199-214.

23. Henao, F.; Cherni, J.; Jaramillo, P.; Dyner, I. A multicriteria approach to sustainable energy supply for the rural poor. Eur. J. Oper. Res. 2012, 218, 801-809. [CrossRef]

24. Hitzeroth, M.; Megerle, A. Renewable energy projects: Acceptance risks and their management. Renew. Sustain. Energy Rev. 2013, 27, 576-584. [CrossRef] 
25. Hindmarsh, R.; Matthews, C. Deliberative speak at the turbine face: Community engagement, windfarms, and renewable energy transitions, in Australia. J. Environ. Policy Plan. 2008, 10, 217-232. [CrossRef]

26. Stigka, E.; Paravantis, J.; Mihalakakou, G. Social acceptance of renewable energy sources: A review of contingent valuation applications. Renew. Sustain. Energy Rev. 2014, 32, 100-106. [CrossRef]

27. Tilt, B.; Braun, Y.; He, D. Social impacts of large dam projects: A comparison of international case studies and implications for best practice. J. Environ. Manag. 2009, 90, S249-S257. [CrossRef] [PubMed]

28. McCartney, M. Living with dams: Managing the environmental impacts. Water Policy 2009, 11, 121-139. [CrossRef]

29. Devine-Wright, P. Local aspects of renewable energy development in the UK: Public beliefs and policy implications. Local Environ. 2005, 10, 57-69. [CrossRef]

30. Devine-Wright, P. Beyond NIMBYism: Towards an integrated framework for understanding public perceptions of wind energy. Wind Energy 2005, 8, 125-140. [CrossRef]

31. Troncoso, K.; Castillo, A.; Masera, A.; Merino, L. Social perceptions about a technological innovation for fuelwood cooking: Case study in rural Mexico. Energy Policy 2007, 35, 2799-2810. [CrossRef]

32. Ashley, C.; Carney, D. Sustainable Livelihoods: Lessons from Early Experience, Vol. 7; Department for International Development: London, UK, 1999.

33. Chambers, R.; Conway, R. Sustainable Rural Livelihoods: Practical Concepts of the 21st Century; Institute of Development Studies: Brighton, UK, 1992.

34. Department for International Development. Sustainable Livelihoods Guidance Sheets; DFID: London, UK, 2000.

35. Department for International Development. Energy for the Poor: Underpinning the Millennium Development Goals; DFID: London, UK, 2002.

36. Ellis, F. Rural Livelihoods and Diversity in Developing Countries; Oxford University Press: Oxford, UK, 2000.

37. Bannister, A. The Sustainable Urban Livelihoods Framework-A Tool for Looking at the Links between Energy and Poverty. Boil. Point 2002, 48, 7-10.

38. Barnes, D. Energy and Poverty: Strategies for Assisting the Rural and Urban Poor; Background Paper for the World Bank Energy Strategy; The World Bank, South Asia Region, Energy Sector Unit: Washington, DC, USA, 2000.

39. Barnett, A. Energy and the Fight against Poverty; Livelihood Sector Report; Department for International Development (DFID): London, UK, 2000.

40. Wils, A.; Kamiya, M.; Choucri, N. Threats to sustainability: Simulating conflict within and between nations. Syst. Dyn. Rev. 1998, 14, 129-162. [CrossRef]

41. Sterman, J. Business Dynamics—Systems Thinking and Modelling for a Complex World; McGraw-Hill Companies, Inc.: New York, NY, USA, 2000.

42. Stave, K. Using system dynamics to improve public participation in environmental decisions. Syst. Dyn. Rev. 2002, 18, 139-167. [CrossRef]

43. Armah, F.; Yawson, D.; Pappoe, A. A Systems Dynamics Approach to Explore Traffic Congestion and Air Pollution Link in the City of Accra, Ghana. Sustainability 2010, 2, 252-265. [CrossRef]

44. Olabisi, L. The System Dynamics of Forest Cover in the Developing World: Researcher versus Community Perspectives. Sustainability 2010, 2, 1523-1535. [CrossRef]

45. Taylor, T.; Ford, D.; Yvon-Lewis, S.; Lindquist, E. Science, engineering, and technology in the policy process for mitigating natural-Societal risk. Syst. Dyn. Rev. 2011, 27, 173-194. [CrossRef]

46. Fernald, A.; Tidwell, V.; Rivera, J.; Rodríguez, S.; Guldan, S.; Steele, C.; Ochoa, C.; Hurd, B.; Ortiz, M.; Boykin, K.; et al. Modeling Sustainability of Water, Environment, Livelihood, and Culture in Traditional Irrigation Communities and Their Linked Watersheds. Sustainability 2012, 4, 2998-3022. [CrossRef]

47. Gokhan, E.; Omer, T. A dynamic modeling approach to highway sustainability: Strategies to reduce overall impact. Transp. Res. Part A Policy Pract. 2012, 46, 1086-1096.

48. Neely, K.; Walters, J. Using Causal Loop Diagramming to Explore the Drivers of the Sustained Functionality of Rural Water Services in Timor-Leste. Sustainability 2016, 8, 57. [CrossRef]

49. Banson, K.E.; Nguyen, N.C.; Bosch, O.J. Using system archetypes to identify drivers and barriers for sustainable agriculture in Africa: A case study in Ghana. Syst. Res. Behav. Sci. 2014, 33, 79-99. [CrossRef]

50. Senge, P. The Fifth Discipline: The Art and Practice of the Learning Organization; Random House: London, UK, 1990.

51. Jackson, M. Systems Thinking: Creative Holism for Managers; Wiley: Chichester, UK, 2003. 
52. Maani, K.; Cavana, R. Systems Thinking, System Dynamics: Managing Change and Complexity; Prentice Hall: Upper Saddle River, NJ, USA, 2007.

53. Nguyen, N.; Bosch, O. A systems thinking approach to identify leverage points for sustainability: A case study in the Cat Ba Biosphere Reserve, Vietnam. Syst. Res. Behav. Sci. 2013, 30, 104-115. [CrossRef]

54. Hindle, G.; Franco, L. Combining problem structuring methods to conduct applied research: A mixed methods approach to studying fitness-to-drive in the UK. J. Oper. Res. Soc. 2009, 60, 1637-1648. [CrossRef]

55. Ilskog, E.; Kjellström, B. And then they lived sustainably ever after?-Assessment of rural electrification cases by means of indicators. Energy Policy 2008, 36, 2674-2684. [CrossRef]

56. United Nations. Indicators of Sustainable Development: Guidelines and Methodologies; United Nations: New York, NY, USA, 2001.

57. Maruyama, Y.; Nishikido, M.; Iida, T. The rise of community wind power in Japan: Enhanced acceptance through social innovation. Energy Policy 2007, 35, 2761-2769. [CrossRef]

58. Rogers, J.; Simmons, E.; Convery, I.; Weatherall, A. Public perceptions of opportunities for community-based renewable energy projects. Energy Policy 2008, 36, 4217-4226. [CrossRef]

59. Del Río, P.; Burguillo, M. Assessing the impact of renewable energy deployment on local sustainability: Towards a theoretical framework. Renew. Sustain. Energy Rev. 2008, 12, 1325-1344. [CrossRef]

60. Kaygusuz, K. Energy services and energy poverty for sustainable rural development. Renew. Sustain. Energy Rev. 2011, 15, 936-947. [CrossRef]

61. Parikh, J. Hardships and health impacts on women due to traditional cooking fuels: A case study of Himalchal Pradesh, India. Energy Policy 2011, 39, 7587-7594. [CrossRef]

62. Mahat, I. Gender, energy, and empowerment: A case study of the Rural Energy Development Program in Nepal. Dev. Pract. 2011, 21, 405-420. [CrossRef]

63. Commission of the European Communities. Solar Energy for Development. In Proceedings of the International Conference, Varese, Italy, 26-29 March 1979; Martinus Nijhoff Publishers: The Hague, The Netherlands, 1979.

64. Ding, W.; Wang, L.; Chen, B.; Xu, L.; Li, H. Impacts of renewable energy on gender in rural communities of north-west China. Renew. Energy 2014, 69, 180-189. [CrossRef]

65. Akella, A.K.; Saini, R.P.; Sharma, M.P. Social, economical and environmental impacts of renewable energy systems. Renew. Energy 2009, 32, 390-396. [CrossRef]

66. Biswas, W.K.; Bryce, P.; Diesendorf, M. Model for empowering rural poor through renewable energy technologies in Bangladesh. Environ. Sci. Policy 2001, 4, 333-344. [CrossRef]

67. Painuly, J.; Fenhann, J. Implementation of Renewable Energy Technologies-Opportunities and Barriers; Summary of Country Studies; Risø National Laboratory, UNEP Collaborating Centre on Energy and Environment: Roskilde, Denmark, 2002.

68. Bhide, A.; Monroy, C.R. Energy poverty: A special focus on energy poverty in India and renewable energy technologies. Renew. Sustain. Energy Rev. 2011, 15, 1057-1066. [CrossRef]

69. Domenech, B.; Ferrer-Martí, L.; Lillo, P.; Pastor, R.; Chiroque, J. A community electrification project: Combination of microgrids and household systems fed by wind, PV or micro-hydro energies according to micro-scale resource evaluation and social constraints. Energy Sustain. Dev. 2014, 23, 275-285. [CrossRef]

70. Sagar, A. Alleviating energy poverty for the world's poor. Energy Policy 2005, 33, 1367-1372. [CrossRef]

71. Shamsuzzoha, A.; Grant, A.; Clark, J. Implementation of renewable energy in Scottish rural area: A social study. Renew. Sustain. Energy Rev. 2012, 16, 185-191. [CrossRef]

72. Karytsas, S.; Theodoropoulou, H. Socioeconomic and demographic factors that influence publics' awareness on the different forms of renewable energy sources. Renew. Energy 2014, 71, 480-485. [CrossRef]

73. Yuan, X.; Zuo, J.; Ma, C. Social acceptance of solar energy technologies in China-End users' perspective. Energy Policy 2011, 39, 1031-1036. [CrossRef]

74. Qu, M.; Ahponen, P.; Tahvanainen, L.; Gritten, D.; Mola-Yudego, B.; Pelkonen, P. Chinese university students' knowledge and attitudes regarding forest bio-energy. Renew. Sustain. Energy Rev. 2011, 25, 3649-3657. [CrossRef]

75. Çelikler, D. Awareness about renewable energy of pre-service science teachers in Turkey. Renew. Energy 2013, 60, 343-348. [CrossRef]

76. Liu, W.; Wang, C.; Mol, A. Rural public acceptance of renewable energy deployment: The case of Shandong in China. Appl. Energy 2013, 102, 1187-1196. [CrossRef] 
77. Moula, M.; Maula, J.; Hamdy, M.; Fang, T.; Jung, N.; Lahdelma, R. Researching social acceptability of renewable energy technologies in Finland. Int. J. Sustain. Built Environ. 2013, 2, 89-98. [CrossRef]

78. Zyadin, A.; Puhakka, A.; Ahponen, P.; Pelkonen, P. Secondary school teachers' knowledge, perceptions, and attitudes toward renewable energy in Jordan. Renew. Energy 2014, 62, 341-348. [CrossRef]

79. Blenkinsopp, T.; Coles, S.; Kirwan, K. Renewable energy for rural communities in Maharashtra, India. Energy Policy 2013, 60, 192-199. [CrossRef]

80. Terrapon, J.; Dienst, C.; König, J.; Ortiz, W. A cross-sectional review: Impacts and sustainability of small-scale renewable energy projects in developing countries. Renew. Sustain. Energy Rev. 2014, 40, 1-10. [CrossRef]

81. Holm, D. Renewable energy future for the developing world. Trans. Renew. Energy Syst. 2013. [CrossRef]

82. Abdul-Rahman, H.; Berawi, M.A.; Berawi, A.R.; Mohamed, O.; Othman, M.; Yahya, I.A. Delay mitigation in the Malaysian construction industry. J. Constr. Eng. Manag. 2006, 132, 125-133. [CrossRef]

83. Pietrosemoli, L.; Rodríguez, C. The impact of sustainable construction and knowledge management on sustainability goals. A review of the Venezuelan renewable energy sector. Renew. Sustain. Energy Rev. 2013, 27, 683-691. [CrossRef]

84. Bautista, S. A sustainable scenario for Venezuelan power generation sector in 2050 and its costs. Energy Policy 2012, 44, 331-340. [CrossRef]

85. Tsoutsos, T.; Frantzeskaki, N.; Gekas, V. Environmental impacts from the solar energy technologies. Energy Policy 2005, 33, 289-296. [CrossRef]

86. City of Vancouver. Clouds of Change: Final Report of the City of Vancouver Task Force on Atmospheric Change; City of Vancouver: Vancouver, BC, Canada, 1990.

87. Pietilä, H. Environment and Sustainable Development, IFDA Dossier 77; International Foundation for Development Alternatives: Nyon, Switzerland, 1990; pp. 61-70.

88. Haughton, G.; Hunter, C. Sustainable Cities, Regional Policy and Development Series 7; Regional Studies Association: London, UK, 1994.

89. Wackernagel, M.; Rees, W. Our Ecological Footprint: Reducing Human Impact on the Earth (No. 9); New Society Publishers: Gabriola Island, BC, Canada, 1998.

90. Fouquet, D.; Johansson, T. European renewable energy policy at crossroads-Focus on electricity support mechanisms. Energy Policy 2008, 36, 4079-4092. [CrossRef]

91. Stadelmann, M.; Castro, P. Climate policy innovation in the South-Domestic and international determinants of renewable energy policies in developing and emerging countries. Glob. Environ. Chang. 2014, 29, 413-423. [CrossRef]

92. Inglesi-Lotz, R. The impact of renewable energy consumption to economic growth: A panel data application. Energy Econ. 2016, 53, 58-63. [CrossRef]

93. Sadorsky, P. Renewable energy consumption and income in emerging economies. Energy Policy 2009, 37, 4021-4028. [CrossRef]

94. United Nations Development Programme. Towards an "Energy Plus" Approach for the Poor: A Review of Good Practices and Lessons Learned from Asia and the Pacific; UNDP: Bangkok, Thailand, 2011.

95. The World Bank. The Welfare Impact of Rural Electrification: A Reassessment of the Costs and Benefits. An IEG Impact Evaluation; The World Bank: Washington, DC, USA, 2008.

96. Roy, K. Neglected issues in technological change and rural development: An overview. In Technological Change and Rural Development in Poor Countries; Oxford University Press: Oxford, UK, 1994.

97. The Guardian. Investing in Off-Grid Renewables in the Developing World: What You Need to Know; The Guardian: London, UK, 2016.

98. Painuly, J. Barriers to renewable energy penetration; a framework for analysis. Renew. Energy 2001, 24, 73-89. [CrossRef]

99. Kapadia, K. Productive Uses of Renewable Energy: A Review of Four Bank-GEF Projects; The World Bank: Washington, DC, USA, 2004.

100. Shrestha, R.; Kumar, S.; Martin, S.; Urmee, T. Application of Productive Uses of Renewable Energy for Small, Medium and Micro Enterprises. In Proceedings of the UNDP Expert Meeting on Productive Uses of Renewable Energy, Bangkok, Thailand, 9-11 May 2005.

101. De Gouvello, C.; Durix, L. Maximizing the Productive Uses of Electricity to Increase the Impact of Rural Electrification Programs; ESMAP, The World Bank: Washington, DC, USA, 2008. 
102. Karekezi, K.; Kithyoma, W. Renewable energy strategies for rural Africa: Is a PV-led renewable energy strategy the right approach for providing modern energy to the rural poor of sub-Saharan Africa? Energy Policy 2002, 30, 1071-1086. [CrossRef]

103. Fredriksson, P.; Svensson, J. Political instability, corruption and policy formation: The case of environmental policy. J. Public Econ. 2003, 87, 1383-1405. [CrossRef]

104. Lopez, R.; Mitra, S. Corruption, pollution, and the Kuznets environment curve. J. Environ. Econ. Manag. 2000, 40, 137-150. [CrossRef]

105. Potrafke, N. Does government ideology influence deregulation of product markets? Empirical evidence from OECD countries. Public Choice 2010, 143, 135-155. [CrossRef]

106. Pansera, M. Renewable energy for rural areas of Bolivia. Renew. Sustain. Energy Rev. 2012, 16, 6694-6704. [CrossRef]

107. World Bank. Meeting the Challenge for Rural Energy and Development; The World Bank: Washington, DC, USA, 1999.

108. United Nations. Transforming Our World: The 2030 Agenda for Sustainable Development. Resolution Adopted by the General Assembly on 25 September 2015; United Nations: New York, NY, USA, 2015.

109. Cherni, J.; Hill, Y. Energy and policy providing for sustainable rural livelihoods in remote locations-The case of Cuba. Geoforum 2009, 40, 645-654. [CrossRef]

110. Nepal, R. Roles and potentials of renewable energy in less-developed economies: The case of Nepal. Renew. Sustain. Energy Rev. 2012, 16, 2200-2206. [CrossRef]

111. Sarraf, M.; Rismanchi, B.; Saidur, R.; Ping, H.; Rahim, W. Renewable energy policies for sustainable development in Cambodia. Renew. Sustain. Energy Rev. 2013, 22, 223-229. [CrossRef]

(C) 2016 by the authors; licensee MDPI, Basel, Switzerland. This article is an open access article distributed under the terms and conditions of the Creative Commons Attribution (CC-BY) license (http:/ / creativecommons.org/licenses/by/4.0/). 